\title{
Ssciendo
}

DOI 10.2478/afepuc-2020-0017

(C) Acta Facultatis Educationis Physicae Universitatis Comenianae 2020, 60(2): 207-216

\section{CHANGES IN THE START REACTION TIMES IN THE 200 m RUN AT THE WORLD CHAMPIONSHIPS AFTER THE TIGHTENING OF FALSE START RULE}

\author{
Peter Mitašík, Ladislava Doležajová, Anton Lednický, Dávid Végh \\ Comenius University in Bratislava, Faculty of Physical Education and Sports, Slovakia
}

\begin{abstract}
Summary: Reaction time is an important component of the structure of sports performance in sprint disciplines. In our observation, we focused on the men's and women's 200 metres discipline at the World Championships (WCH) in two periods. The first in 1999-2009 and the second in 2011-2019. This division was conditioned by the change in the false start rule, which states that any competitor who makes a false start, except in multicontest, will be disqualified (valid since 1st January 2010). This change affected the speed of the sprinter's reaction. The monitored group were finalists of the $200 \mathrm{~m}$ runs at the $\mathrm{WCH}$, a total of 11 events. We used basic mathematical-statistical characteristics and assessed changes in reaction times using parametric paired and parametric unpaired t-test and Wilcoxon test. We compared reaction time in the heats and the finals. We found that at some $\mathrm{WCH}$, worse reaction times were achieved in the finals of both categories compared with the heats. By comparing the reaction speed in the heats with the reaction speed in the men's finals, we recorded this statistically significant difference in the first period $(p<0.01)$ and after tightening the rule at the level of $p<0.10$. In the women's group, this difference was not statistically significant in any period. The percentage of the reaction speed in the final time of the 200 $m$ run was $0.76-0.86 \%$ in the men's group and $0.74-0.78 \%$ in the women's group. The analysis of the results from the WCH in athletics confirmed the importance of reaction speed in the $200 \mathrm{~m}$ run.
\end{abstract}

Keywords: World Athletics Championships, reaction time, men's and women's $200 \mathrm{~m}$ running, heats, finals, IAAF (WA)

\section{Introduction}

The structure of sports performance is a complex, versatile and variable system. It is necessary to take into consideration the interconnections and relationships between individual parts instead of studying them as separate factors (Koštial 1984). The author emphasised that there is a specific hierarchy (the genesis of the structure) between the individual factors of the 
whole. Short distances are characterised by maximum load intensity in order to cover a given distance in the shortest possible time. As reaction time is a necessary part of these disciplines, Kampmiller \& Koštial (1986), Sedláček (1992) have already included the ability to react in the first factor level in the structure of youth sports performance in the $100 \mathrm{~m}$ run $(14.2 \%$ share in total performance). In addition, among the limiting factors of achieving performance in athletic sprint disciplines belongs the maximum running speed and the ability to maintain it during performance at speed - referred to as endurance in speed (Kampmiller \& Koštial, 1986). Unlike these authors, Choutka (1976) classified reaction speed in relation to sports performance into the second-factor level. The speed of response is influenced by several factors: age, gender, physiological and psychological abilities, fatigue, warm-up, athletic age, intelligence, anticipation (Schweitzer 2001; Luchies et al. 2002; Barral \& Debu 2004; Van der Berg and Neely 2006; Kohen et al. 2008; Zemková 2011; Hodgkins 2013). The study by Adam et al. (1999) considered the hypothesis that men and women use other information processing strategies to create responses to given tasks. This fact was also confirmed by Brosnan, Hayes \& Harrison (2016), who found significant differences in the reaction speed of elite athletes. Based on this, they recommended different limits to determine the violation of the response speed rule. Instead of the current $0.100 \mathrm{~s}$ for both categories, they recommend a limit of 0.115 $\mathrm{s}$ for men and $0.119 \mathrm{~s}$ for women.

The results are in favour of men, who achieved a much faster reaction time than women in a selective, compatible, and incompatible task that required a verbal response. Its significant position can be easily demonstrated with a sprint at $100 \mathrm{~m}$. As the author Ozolin (1986) and Kuchen (1978) state, if we theoretically imagine two athletes with a difference in the start reaction of $20 \mathrm{~ms}$, it would be reflected as a $20 \mathrm{~cm}$ distance in the finish, which is at the current differences in performance often the length difference between the first and fifth competitor. Although the share of reaction time in sports performance is getting smaller with increasing running distance, it is important to realise that the result is often decided by hundredths of seconds (Delalija \& Babić 2008). Their research was also focused on reaction time as the first factor in the time sequence of the sprint. The sample included 250 women and 360 men from the 2004 Olympic Games in Athens. The research aimed to determine the effect of reaction time on the result of the sprint. The authors statistically proved a significant correlation between the reaction time and the achieved performance in the women's $100 \mathrm{~m}$ hurdles and the men's $100 \mathrm{~m}$ and $110 \mathrm{~m}$ hurdles. At $200 \mathrm{~m}$, a significant linear increase in the mean reaction time was demonstrated at start (Baumann 1980; Babic \& Delalija 2009). The authors Locatelli and Arsac (1995) stated that this is mainly due to the fact that the $200 \mathrm{~m}$ runners are aware of the small 
share of the reaction time in their final performance. We believe that a factor such as reaction speed must be approached as responsibly and with sufficient emphasis as the development of other skills. The speed of the reaction could also be influenced by the rules of athletics about start in short distances (rule no. 162). Changes in the number of false starts and tightening of the criteria for excluding an athlete could have affected the speed of the sprinter's reaction. The 2009 rule (effective from 1 January 2010) stipulated that the reaction rate should not be below $0.100 \mathrm{~s}$. Since then, any competitor who makes a false start (except for multicontest) will be disqualified. After taking the final start position, the competitor must not start moving before the gun is fired. If in the opinion of the starter or a deputy - starter assistant, the athlete begins the movement earlier, it is considered a false start (IAAF Rules of Athletics 2018 - 2019).

This paper aimed to compare the reaction times at the start of men and women finalists of the $200 \mathrm{~m}$ World Championships in the years 1999 to 2019. The criterion for comparing the speed of reaction in the monitored groups (1999-2009, resp. 2011-2019) was the rule tightening on the exclusion of an athlete at the start.

\section{Hypotheses}

H1 We assume a statistically significant improvement of the start reactions in the final runs at individual $\mathrm{WCH}$ in comparison with the heats in the group of men and women in the whole monitored period.

H2 We assume, due to the rule change of a false start, we will find a statistically significant deterioration of the start reactions in the WCH at the period of 2011-2019 in comparison with the period of 1999-2009 at the heats and the finals of men and women.

H3 We assume statistically significantly better values of start reactions of men and women in the finals in comparison with the heats at the WCH in the first and second period, as well.

\section{Tasks}

1. Find and evaluate start reaction data from the official website of the IAAF (WA - World Athletics) from the WCH 1999-2019.

2. Analyse, compare, and statistically prove changes in start reactions in individual disciplines.

\section{Methods}

\section{Participants}

We researched men and women sprinters in the $200 \mathrm{~m}$ runs, who took part in the finals at the WCH in Athletics in the years 1999-2019. The group consisted of 348 athletes (176 men and 172 women). 


\section{Procedure}

We obtained the values of the start reactions of sprinters from the mentioned period from the official website of the IAAF (WA). We calculated their percentage share of performance.

\section{Statistical analysis}

In the calculations, we used the basic statistical characteristics (Tab. 1): arithmetic mean $(\mathrm{x})$, standard deviation $(\mathrm{s})$, minimum value $\left(\mathrm{x}_{\min }\right)$, maximum value $\left(\mathrm{x}_{\max }\right)$ and variation range $\left(\mathrm{v}_{\mathrm{r}}\right)$. We determined the statistical significance of changes (heats vs finals at individual $\mathrm{WCH}$ ) using the Wilcoxon t-test. We used parametric paired and parametric unpaired t-test to compare the differences in the reaction speed in the monitored periods. The normality of the distribution was assessed by the Shapiro-Wilk test.

\section{Results}

The first hypothesis was the assumption that in each observed period, both men and women achieve faster start reactions in the final runs compared to the heats (Fig. 1, Fig. 2).

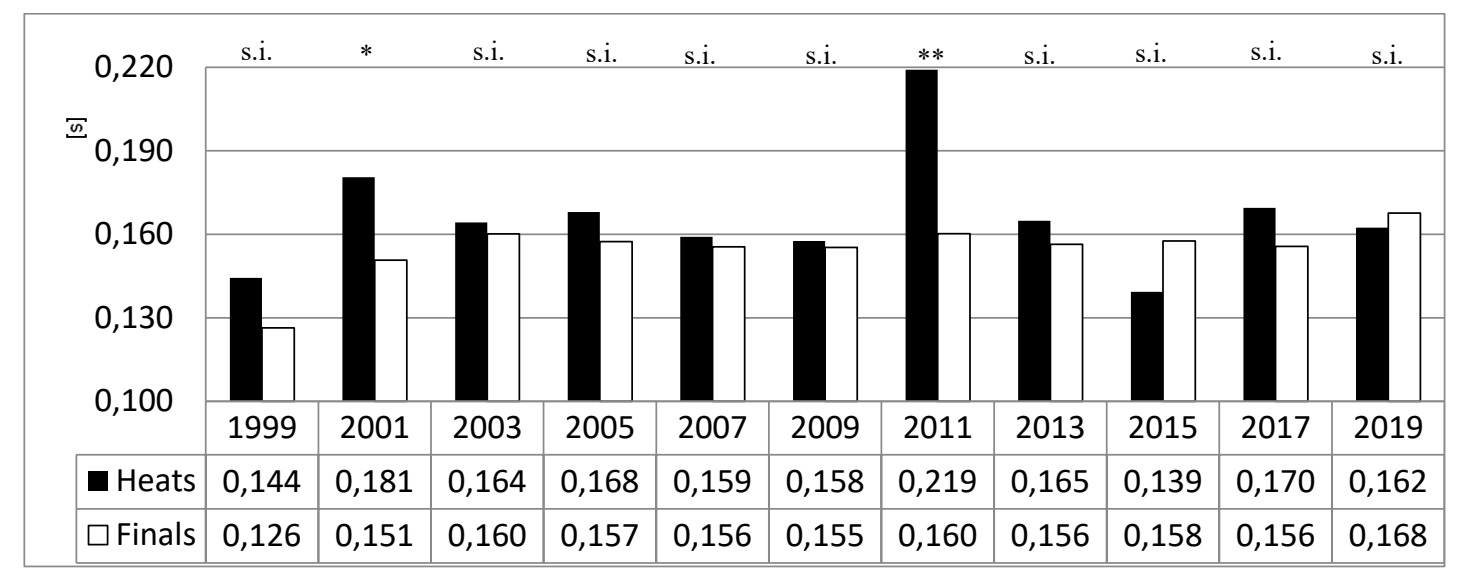

Legend: ${ }^{*} \mathrm{p}<0,05 ; * * \mathrm{p}<0,01 ;$ s.i. - statistically insignificant

Figure 1

Comparison of the average values of men's start reactions $(n=8)$ in the 200 m run from 1999 to 2019 at the World Athletics Championships

Figure 1 shows that men achieved, on average, faster start reactions in the finals at almost all WCH. In $2001(\mathrm{p}<0.05)$ and $2011(\mathrm{p}<0.01)$ the changes were statistically significant. In contrast, during 2015 and 2019, there was a deterioration in the speed of reaction in the finals (by $12.02 \%$ and $3.57 \%$, respectively). 


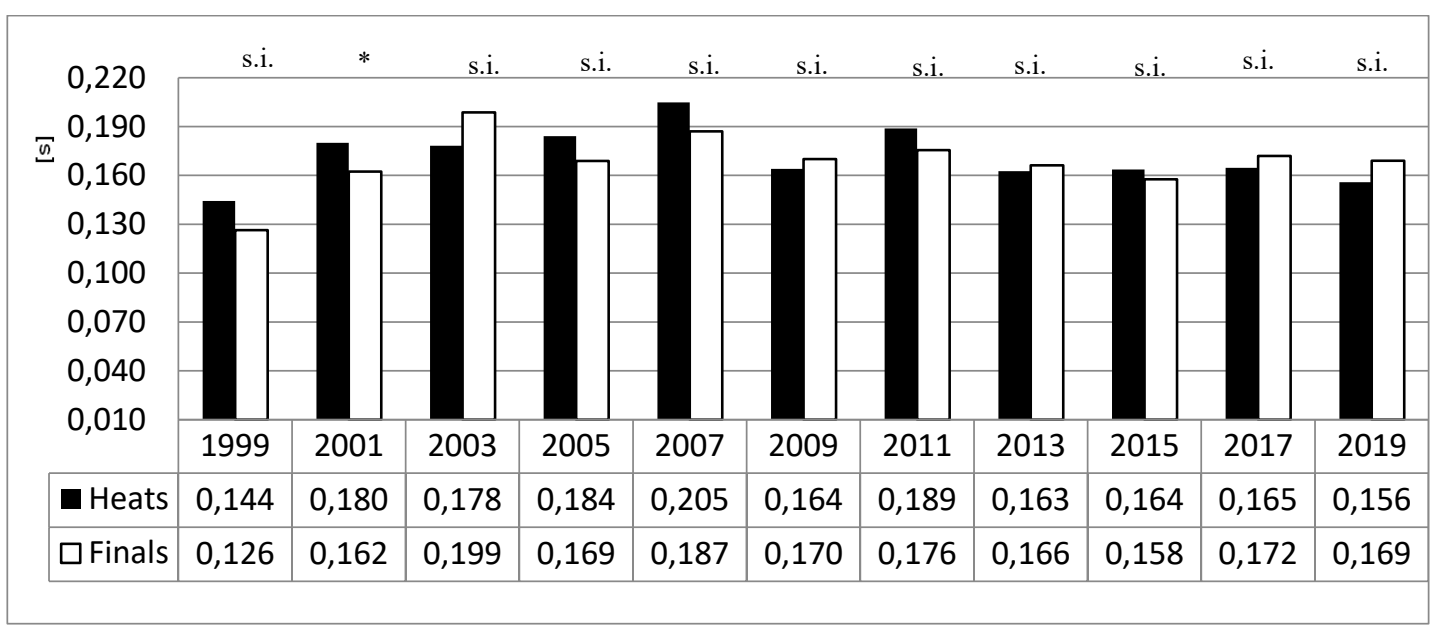

Legend: ${ }^{*} \mathrm{p}<0,05$; s.i. - statistically insignificant

Figure 2

Comparison of the average values of women's start reactions $(n=8)$ in the 200 m run from 1999 to 2019 at the World Athletics Championships.

In Fig. 2, it can be seen that the women achieved an improvement in the mean start reactions in $6 \mathrm{WCH}$. We recorded a deterioration in the average start reactions in the finals at five $\mathrm{WCH}$, in 2003, 2009, 2013, 2017 and 2019. The average value of the improvement of the start reaction was $9.16 \%$. The average deterioration in the reaction rate was $5.51 \%$. Based on these results, we can state that we did not confirm $\mathrm{H} 1$.

In $\mathrm{H} 2$, we assumed that due to the change in the rule of the false start, we would find a statistically significant deterioration of the start reactions in the $\mathrm{WCH}$ during the second period (2011-2019) compared to the first (1999-2009) in the heats and finals of men and women. Table 1 shows the basic statistical characteristics of the observed periods, and Table 2 shows their statistical significance of differences.

Table 1

Basic statistical characteristics of men $(M)$ and women $(W)$ in heats and the finals in the $200 \mathrm{~m}$ run at the World Championships 1999-2019

\begin{tabular}{|l|c|c|c|c|c|c|}
\hline Category and period & $\mathbf{X}$ & $\mathbf{M e}$ & $\mathbf{S}$ & $\mathbf{x}_{\min }$ & $\mathbf{x}_{\max }$ & $\mathbf{v}_{\mathbf{r}}$ \\
\hline M heats 1999-2009 $(\mathrm{n}=48)$ & 0,162 & 0,159 & 0,023 & 0,124 & 0,229 & 0,105 \\
\hline M finals 1999-2009 $(\mathrm{n}=48)$ & 0,151 & 0,156 & 0,016 & 0,124 & 0,186 & 0,062 \\
\hline M heats 2011-2019 $(\mathrm{n}=40)$ & 0,175 & 0,165 & 0,039 & 0,128 & 0,314 & 0,186 \\
\hline M finals 2011-2019 $(\mathrm{n}=40)$ & 0,160 & 0,161 & 0,018 & 0,119 & 0,198 & 0,079 \\
\hline W heats 1999-2009 $(\mathrm{n}=46)$ & 0,178 & 0,169 & 0,04 & 0,133 & 0,367 & 0,234 \\
\hline W finals 1999-2009 $(\mathrm{n}=46)$ & 0,174 & 0,172 & 0,039 & 0,124 & 0,277 & 0,153 \\
\hline W heats 2011-2019 $(\mathrm{n}=40)$ & 0,167 & 0,161 & 0,023 & 0,136 & 0,238 & 0,102 \\
\hline W finals 2011-2019 $(\mathrm{n}=40)$ & 0,168 & 0,162 & 0,021 & 0,138 & 0,228 & 0,09 \\
\hline
\end{tabular}

Legend: $\mathrm{Me}-$ median, $\mathrm{x}$ - arithmetic mean, $\mathrm{s}-$ standard deviation, $\mathrm{x}_{\min }-$ minimum value, $\mathrm{x}_{\max }-$ maximum value, $\mathrm{v}_{\mathrm{r}}$ - variation range, $\mathrm{M}-$ men, $\mathrm{W}-$ women 
Table 2

Statistical significance of differences in reaction times in heats and the finals of the $200 \mathrm{~m}$ men's and women's run at the World Championships in Athletics

\begin{tabular}{|c|l|c|l|l|c|l|}
\hline Period & 1999-2009 & t-test & $\mathbf{2 0 1 1 - 2 0 1 9}$ & $\mathbf{1 9 9 9 - 2 0 0 9}$ & t-test & 2011-2019 \\
\hline M & Heats & s.i. & Heats & Finals & s.i. & Finals \\
\hline W & Heats & s.i. & Heats & Finals & s.i. & Finals \\
\hline
\end{tabular}

Legend: s.i. - statistically insignificant, $\mathrm{M}-$ men, $\mathrm{W}$ - women

In the heats, men's reaction time in the second period was $0.175 \mathrm{~s}$, which was a deterioration of $5.56 \%$ compared to the first period $(0.162 \mathrm{~s})$. There was a similar trend in the final runs. In the years $2011-2019$, the reaction rate deteriorated to 0.160 s (i.e. by $5.96 \%$ ) compared to the years 1999-2009, in which the average reaction rate time was $0.151 \mathrm{~s}$. However, this deterioration was not statistically significant either in the heats or in the finals. In the women's group, we found an improvement in average times by $6.18 \%(0.178 \mathrm{~s}$ and 0.167 $\mathrm{s}$, respectively). In the final, there was an improvement of $3.45 \%(0.174 \mathrm{~s}$ and $0.168 \mathrm{~s}$, respectively). However, even these differences were not statistically significant. We state that we did not confirm $\mathrm{H} 2$.

In H3, we assumed that in the monitored periods (1999-2009, respectively 2011-2019), both men and women would achieve faster start reactions in the finals than in the heats. Table 3 shows that in the first period, this difference was statistically significant in men at the level of $p<0.01$ and after tightening the rule at the level of $p<0.10$. In women, this difference was not statistically significant in any period.

Table 3

Statistical significance of differences in reaction times in heats and in the finals of the World Championships in Athletics

\begin{tabular}{|c|l|c|l|l|c|c|l|}
\hline Period & \multicolumn{3}{|c|}{ 1999-2009 } & & \multicolumn{3}{c|}{$\mathbf{2 0 1 1 - 2 0 1 9}$} \\
\hline $\mathrm{M}(\mathrm{n}=48)$ & Heats & $\mathrm{p}<0,01$ & Finals & $\mathrm{M}(\mathrm{n}=48)$ & Heats & $\mathrm{p}<0,10$ & Finals \\
\hline $\mathrm{W}(\mathrm{n}=46)$ & Heats & s.i. & Finals & $\mathrm{W}(\mathrm{n}=46)$ & Heats & s.i. & Finals \\
\hline
\end{tabular}

Legend: s.i. - statistically insignificant, $\mathrm{M}-$ men, $\mathrm{W}$ - women

The importance of the reaction speed is confirmed by its percentage share in the final time of sprinters in the $200 \mathrm{~m}$ run (Table 4).

Table 4

Reaction times and their percentage share of the achieved performance in the $200 \mathrm{~m}$ run in the period 19992009 and 2011-2019

\begin{tabular}{|c|c|c|c|c|c|c|c|c|}
\hline \multirow{3}{*}{ Period } & \multicolumn{4}{|c|}{ Men } & \multicolumn{4}{c|}{ Women } \\
\cline { 2 - 9 } & \multicolumn{2}{|c|}{ Heats } & \multicolumn{2}{c|}{ Finals } & \multicolumn{2}{c|}{ Heats } & \multicolumn{2}{c|}{ Finals } \\
\cline { 2 - 9 } & RT [s] & $\%$ share & RT [s] & \% share & RT [s] & \% share & RT [s] & $\%$ share \\
\hline $1999-2009$ & 0,162 & 0,79 & 0,151 & 0,76 & 0,178 & 0,78 & 0,174 & 0,77 \\
\hline $2011-2019$ & 0,175 & 0,86 & 0,160 & 0,79 & 0,167 & 0,74 & 0,168 & 0,75 \\
\hline
\end{tabular}

Legend: RT - reaction time 


\section{Discussion}

The first hypothesis about the improvement of start reactions in the final runs was not confirmed. Men at two $\operatorname{WCH}(2015,2019)$ and women at five $\operatorname{WCH}(2003,2009,2013,2017$, 2019) achieved worse reaction times in the finals than in the heats.

In the second hypothesis, we assumed statistically significant differences in the reaction speed in the heats and the finals in the first (1999-2009) and the second (2011-2019) period. Our assumption was not confirmed in any of the groups. We did not confirm the third hypothesis about better reaction times in the finals in each period and both categories.

Among men, we showed a statistically significant improvement in the reaction speed in the finals in the first and second periods, but not in women. By tightening the rule of exclusion of the sprinter in the event of a false start, the statistical significance was reduced from $\mathrm{p}<0.01$ to $\mathrm{p}<0.10$. Our results confirmed the conclusions of Pilianidis, Mantzouranis \& Kasabalis (2012), who noted a deterioration in the reaction speed of top sprinters following the introduction of the new rule on a false start. Similar results were presented by Haugen, Shalfawi \& Tønnessen (2013). However, women did not confirm this trend. The reaction speed in the second period was higher in the heats $(0.178$ and $0.167 \mathrm{~s}$, respectively) and the finals $(0.174 \mathrm{~s}$ and $0.168 \mathrm{~s}$, respectively) than before the rule tightening. These results confirmed the conclusions of Englert \& Bertrams (2014), who stated that reaction skills could be improved through regular and systematic training, so it is necessary to monitor and pay attention to the reaction time in the training process. In a sample of 37 runners, the authors showed that the strength of self-control of athletes influences the value of reaction time. The result depends on the level of difficulty of the tasks performed by the athlete before the start. The fact that the reaction speed often decides the overall ranking is also proven by several data from the $\mathrm{WCH}$ in the $200 \mathrm{~m}$ run (Helsinki, 2005). Bronze runner Arron (FRA) and the second in the order Boone-Smith (USA) had the same final time in the finals (22.31 s). Arron's reaction time was 0.184 , which was the second slowest reaction time in the finals. Smith won a silver medal with a reaction time of $0.161 \mathrm{~s}$. At the $\mathrm{WCH}$ in Moscow (2013), the silver runner Ahouré (FRA) and the bronze Okagbare (Nigeria) reached the same time in the final run (22.32 s). Thanks to good reaction time, Okagbare $(0.154 \mathrm{~s})$ matched the faster runner in 2 nd place, Ahouré, who had a reaction time of $0.180 \mathrm{~s}$. A similar situation occurred in the men's running finals in Beijing (2015). Fourth in the final run, Edward (Panama) and third Jobodwana (JAR) reached the same time $19.87 \mathrm{~s}$. The placement was again determined by the reaction time, which Edward had $0.170 \mathrm{~s}$ and Jobodwana $0.154 \mathrm{~s}$. Barral \& Debu, (2004) and Hodgkins (2013) found that men have faster start reaction compared to women. We confirmed this conclusion in our 
investigation in three comparisons. We found the opposite trend - a better reaction time for women - in the period after the rule was tightened. In the heats, women had a faster reaction time $(0.167 \mathrm{~s})$ than men $(0.175 \mathrm{~s})$. During this period, in the final runs, the reaction speed was in favour of men $(0.160 \mathrm{~s}$ and $0.168 \mathrm{~s}$, respectively).

\section{References}

1. ADAM, J., F. PAAS, M. BUEKERS, I. WUYTS, W. SPIJKERS \& P. WALLMEYER, 1999. Gender differences in choice reaction time: evidence for differential strategies. In: Journal Ergonomics [online] 1999. Volume 42, Issue 2, 327-335. [updated November 2010], [cited 14.06.2020]. Accessible from < https://doi.org/10.1080/001401399185685>.

2. BABIC, V. \& A. DELALIJA, 2009. Reaction Time Trends in the Women's Sprint and Hurdle Events at the 2004 Olympic Games. In: New Studies in Athletics [online] 2009. [updated 2009], [cited 15.06.2020]. Accessible from < https://www.bib.irb.hr/424620>.

3. BARRAL, J. \& B. DEBÛ, 2009. Aiming in adults: sex and laterality effects. In: Laterality [online] 2009, Volume 9, Issue 3, 299 - 312. [updated June 2010], [cited 08.06.2020]. Accessible from

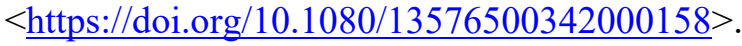

4. BROSNAN, C. K., K. HAYES, \& J. A. HARRISON, 2017. Effects of false-start disqualification rules on response-times of elite-standard sprinters. In: Journal of Sports Sciences [online] 2017, Volume 35, Issue 10, 929-935. [updated June 2016], [cited 28.06.2020]. Accessible from < https://doi.org/10.1080/02640414.2016.1201213>.

5. BAUMANN, W., 1980. Kinematic and dynamic characteristics of the sprint start. In: P.V. Komi (Ed.), Biomechanics V-B. International Series on Biomechanics, Volume 1B, 34-47. Baltimore, MD: University Park Press.

6. CHOUTKA, V., 1976. Teorie a didaktika sportu. Státní pedagogické nakladatelství. Praha.

7. DELALIJA, A., BABIĆ, V. (Assist. Prof.). 2008. Reaction time and sprint results in athletics. In: International Journal of performance analysis in sport [online] July, 2008, Volume 8, Issue 2, 67 -75 [updated April 2017], [cited 14.06.2020]. Accessible from $<$ https://www.tandfonline.com/doi/abs/10.1080/24748668.2008.11868436>.

8. ENGLERS, C., \& A. BERTRAMS, 2014. The effect of ego depletion on sprint start reaction time. In: J Sport Exerc Psychol. [online] September, 2014, Volume 36, Issue 5, 506-515 [updated September 2014], [cited 22.06.2020]. Accessible <from https://doi.org/10.1123/jsep.2014-0029>.

9. HAUGEN, T. A., S. SHALFAWI, \& E. TONNENSSEN, 2012. The effect of different starting procedures on sprinters' reaction time. In: Journal of Sports Sciences [online] 2012, Volume 31, Issue 7, 699-705 [updated December 2012], [cited 05.06. 2020]. Accessible from $<$ https://doi.org/10.1080/02640414.2012.746724>. 
10. HODGKINS, J., 2013. Reaction Time and Speed of Movement in Males and Females of Various Ages. In: Research Quarterly. American Association for Health, Physical Education and Recreation [online] March, 2013, Volume 34, Issue 3, 335 - 343 [updated March 2013], [cited 17.06.2020]. Accessible from $<\underline{\text { https://doi.org/10.1080/10671188.1963.10613242 }}$

11. KAMPMILLER, T. \& J. KOŠTIAL, 1986. Štruktúra a rozvoj rýchlostných schopností v atletických šprintoch mládeže. Praha: ÚVČSSTV.

12. KOHEN, J. D., J. DICKENSON \& D. GOODMAN, 2008. Cognitive demands of error processing. In: PubMed [online] 2008, Volume 102, Issue 2, 532-538 [updated April 2008], [cited 14.6. 2020]. Accessible from $<$ https://doi.org/10.2466/pr0.102.2.532-538>.

13. KOŠTIAL, J., 1984. Účinnost’ tréningového zat’aženia na pohybové schopnosti a výkonnost' mládeže $v$ atletike (na priklade prekážkového behu). Kandidátska dizertačná práca. Bratislava.

14. KUCHEN, A., 1985. Atletika-Encyklopédia. Bratislava: Šport.

15. LOCATELLI, E. \& L. ARSAC, 1995. The mechanics and energetic of the 100m sprint. In: New studies in athletics (by IAAF) [online] 1995, 10:1, 81-87 [updated 1995], [cited 16.6.2020]. Accessible from

$<\mathrm{https}$ ://www.researchgate.net/publication/233810697_The_mechanics_and_energetics_of_the_1 00m_sprint>.

16. LUCHIES, C. W., J. SCHIFFMAN, L. G. RICHARDS, M. R. THOMSON \& D. BAZUIN, 2002. Effects of age, step direction, and reaction condition on the ability to step quickly. In: The Journals of Gerontology [online] 2002, Series A, Volume, Issue 4, 246-249 [updated April 2002], [cited 12.6.2020]. Accessible from $<$ https://doi.org/10.1093/gerona/57.4.M246 $>$.

17. OZOLIN, E. S., 1986. Sprinterskiy beg. Moskva, Fizkul'tura i sport. Učebno-metodičeskoe posobie.

18. Pravidlá atletických sútaži IAAF 2018-2019 (Rules of athletic competitions IAAF 2018-2019). Slovenský atletický zväz. 2017. Bratislava, Pravidlo 129, s. 14.

19. PILIANIDIS, TH., N. MANTZOURANIS \& A. KASABALIS, 2012. Start reaction time and performance at the sprint events in World Athletic Championships. In: International Journal of Performance Analysis in Sport [online] 2012,Volume 12, Issue 1, 112 - 118 [updated April 2017], [cited 24.6.2020]. Accessible from < $\underline{\text { https://doi.org/10.1080/24748668.2012.11868587> }}$

20. SCHWEITZER, K., 2001. Preattentive processing and cognitive ability. In: Science Direct [online] 2001, Volume 29, Issue 2, 169-186 [updated March 2001], [cited 19.6.2020]. Accessible from < https://doi.org/10.1016/S0160-2896(00)00049-0>

21. SEDLÁČEK, J., 1992. Efektivita výberu talentovanej mládeže v behoch na krátke vzdialenosti so zameraním na motorické faktory. Bratislava. Comenius University in Bratislava. Dissertation. Faculty of Physical Education and Sports.

22. VAN DER BERG, J. \& G. NEELY, 2006. Performance on a simple reaction time task while sleepdeprived. In: SAGE Journals [online] 2006, Volume 102, Issue 2, 589-599 [updated April 2006], [cited 22.6.2020]. Accessible from $<\underline{\text { https://doi.org/10.2466/pms.102.2.589-599 }>}$ 
23. ZEMKOVÁ, E., 2011. Fyziologické základy senzomotoriky. Bratislava: ABL Print. pp. 33 - 51. ISBN: 978-80-89257-39-3. 